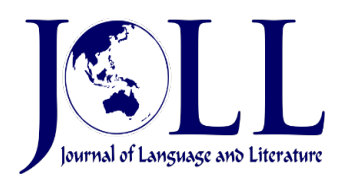

Vol. 21 No. 1, April 2021, pp. $79-91$

DOI: 10.24071/joll.v21i1.2861

Available at https://e-journal.usd.ac.id/index.php/JOLL/index

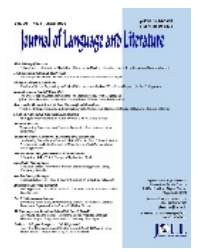

This work is licensed under a Creative Commons Attribution-ShareAlike 4.0 International License.

\title{
Indonesian Woman Migrant Workers Fighting Inequality and Violence in Burung-Burung Migran
}

\author{
Hiqma Nur Agustina \\ hiqma@polinema.ac.id \\ English Department, State Polytechnic of Malang, INDONESIA
}

\begin{abstract}
The story of Indonesian Migrant Workers or Tenaga Kerja Indonesia (TKI) is a blurred portrait of Indonesian citizens' absence in their own country, presented in Burung-burung Migran by Miranda Harlan. This study aims to expose gender inequality, the dominance of structural oppression systems, and poor treatment of woman migrant workers. They struggle to get out of poverty, unemployed, unskilled, and uneducated. The determination and willingness to change destiny is not in line with the reality that often does not side with them. This study uses a qualitative method, narrative strategies about narrator, and focalizations, and gender concepts. The results showed that the focalization and narrator type in the text are internal focalisator and homodiegetic narrator. The focalisator also shows unequal gender relations, physical and verbal violence, which tends to repress Indonesian woman migrant workers. The writer's narrative strategy is in the form of using words, phrases, and sentences that appropriately reflect the repression of female migrant workers.
\end{abstract}

Article

information

Received:

21 September

2020

Revised:

17 November

2020

Accepted:

20 November

2020

Keywords: discrimination; woman migrant worker; focalization; gender relation;

stereotype

\section{Introduction}

As long as they work overseas even until returning home, Indonesian laborers, both legal and illegal, are always controversial regarding departure mechanisms. As foreign exchange heroes, their fate often gains stereotypes and inhumane treatment attributed to their existence as foreign female laborers. Gender relations that tend to be unequal lead to the more discriminatory treatment they receive. Illegal Indonesian women with minimal skills, low educational background, and low-income families are the most frequent targets of these abuses. They dominate the number of migrant workers placed abroad, mainly in the domestic and informal sectors.

In 2016, BNP2TKI reported that Indonesian Women Migrant Workers (TKW) placed 
overseas is 62 percent of the total labor migrants, while the male labor force is only 38 percent (BNP2TKI 2016 in Pusparani, 2017). The report from Badan Perlindungan Pekerja Migran Indonesia (BP2MI) shows that the Indonesian population's enthusiasm to work abroad is relatively high. The latest data on Indonesian Workers' placement for the 20182020 period released by BNP2TKI in September for the 2018-2020 periods stated that 5,186 people were working abroad. This quite drastic decline was due to the Covid-19 pandemic, which caused a large number of Indonesian workers sent home as well as the temporary suspension of sending Indonesian workers abroad (BP2MI, 2020).

Martyn (2018) has conducted a research, which discussed a cross-cultural training model for migrants entering oppressive work environments. This research highlighted the importance of a training model for resistance and empowerment of Indonesian migrant domestic workers' in Hongkong. Balakrisnan (2013) has observed circular and permanent migration as practiced by low-skilled Indonesian labor migrants who have arrived in Peninsular Malaysia since 1980. The problem was about the immigrant workers from Indonesia becoming the largest compared with immigrant workers from Thailand. She tends to classify migrants as the documented immigrants, undocumented migrants, and permanent residents. She also insists that Indonesia and Malaysia should place migrants at the center of their migration policies and management to have a win-win solution to overcome the migrant workers' matters.

The other research done by Constable (2009) observed the migrant domestic workers in Singapore, Taiwan, Malaysia, and especially in the Middle East and the Gulf States. The discussion reveals the migrant workers' protests and activism also support the dynamic of inter-ethnic worker affiliation and the sociohistorical context of Hongkong as a post-colonial global city and a neoliberal space of exception. Woman migrant workers, especially those working in the domestic or household sectors, are the most vulnerable to violence, exploitation, and abuse (Stasilius \& Bakan, 2017). One of the causes of the emergence of problems for Indonesian migrant workers who work as domestic servants (PRT) is the categorization of domestic workers in the informal sector workers. By incorporating domestic work in informal employment, migrant workers will not have significant formal legal protection. This research used a qualitative approach to finding the result.

The pattern of working relations between domestic workers and individual users will have very minimal and subjective supervision. The lack of security afforded to these migrant domestic workers has primarily caused their vulnerability to the multiplicity of layered problems they felt during the migration process, both before, during, and after the migration (Andriyeni, 2017).

The inherent and endless suffering becomes something that often happens to Indonesian migrant workers. A study conducted by Sholihah (2002) in Kuching, Sarawak, on an Indonesian woman migrant worker named Rina (not her real name) originating from Pontianak revealed that she did not have official documents. Her passport was expired a long time ago; as a result, she was arrested by Malaysian authorities. Ironically, she was pregnant and her husband who came from Serikin, Malaysia, was not responsible and abandoned her (2004). At first, in a forced condition due to an invalid passport, Rina was then invited to live in a shelter that underwent buying and selling babies from children of woman migrant workers. With an assistance from LBH APIK Pontianak, an NGO, and the Indonesian consulate in Kuching, Rina returned to Pontianak. Rina's case is among thousands because the mediocre family in Indonesia keeps sending family members to Malaysia for a better life. Rina never earned a salaried from her employer for several years; she was abandoned by her husband; and her unfortunate desire to improve her destiny leads her to the new suffering of having a child without a husband in charge of their lives. 
The novel Burung-burung Migran (2011) by Miranda Harlan becomes the primary source of this research data. The book's exciting side is based on the true story of an Indonesian woman worker who works both illegally and legally and has worked for fourteen years as a migrant worker in Malaysia. Indonesia is known as the most significant labor supplier country in Malaysia. As an illegal foreign worker, Indonesian woman workers are often subjected to repressive and stereotypical treatment from labor agents both before departure to the destination country, waiting to dispatch until they arrive in Malaysia. Assessing the problems related to the issues of Indonesian woman migrant workers working abroad is still very relevant. Indonesian migrant workers have bad luck because they do not get legal protection and regulate a legal rule to protect their status, existence, and rights in a foreign country.

Poor treatment received by illegal Indonesian woman workers in the host country further aggravate if they are caught by the authorities there. Massive raids and deportations carried out by the Malaysian government are the biggest concern for illegal Indonesian workers. It is not surprising because the various treatments related to the bribes of money to release them from prison culminate in an attempt to remain in the neighbor's country.

E-Kad's ownership (Enforcement Card or Legal Worker Card), a temporary card for foreign workers who do not have work permit documents, is an absolute they must have. E-Kad serves to assist the Re-Hiring process (reemployment) and as a temporary worker of the undocumented foreign workers, to stay working while handling official employment documents. The chief secretary of BNP2TKI, Hermono, stated that TKI PATI (Unauthorized Foreign Worker) in Malaysia is the most workers in the construction sector. They find it difficult to get a permanent employer because of the contracting system, which requires many labor migrants to recruit some employer contractors (Hasan, 2017). In this case, illegal Indonesian workers can hardly eliminate. The unlawful search to process foreign workers without the complete official documentation by Malaysian police officers is often traumatic. Forcible repatriation or deportation by the Malaysian government of illegal foreign workers usually has physical and psychological consequences.

Currently, Voluntary Deportation (VD) can make by paying a fine and administration to Malaysian immigration service for 800 Ringgit, using the personal money of each TKI. Through this option, TKI PATI deports without carrying out immigration criminal law procedures of Malaysia, including investigation, trial, and a prison sentence of 3-6 months. If TKI cannot administer the VD, they will be deported under Malaysia's immigration criminal law procedure and would threaten with imprisonment for 3 to 6 months (Hasan, 2017). Penalty received in the form of imprisonment, forced repatriation, or sentences in the way of money to pay for the workers causes deep pain and trauma that lead to psychological issues.

The government of Indonesia made a commitment to ratifying the Convention on the Elimination of Forms of Discrimination against Women or CEDAW (The Convention on the Elimination of All Forms of Discrimination against Women through Law number 7, 1984. They expected to implement the Convention, particularly concerning the principle of state obligations to eliminate various forms of discrimination, both de jure and de facto (based on real facts) (Munti, 2006).

About the Convention, the state obliged to make or amend the law, remove discriminatory stereotypes and customs, and make the necessary efforts or measures required to ensure de facto equality. Discrimination, often accepted by Indonesian migrant workers, should be fought by the state to avoid violence and subordination. The patterns of social and cultural behavior of men and women referring to stereotypical roles are robust (Sitorus, 2006). These stereotypical roles strongly oppress their existence both as women and as women migrant workers who need protection from the state. 
They are called foreign exchange heroes, but they are nothing more than many numbers and statistics in the government's eyes. The various forms of torture and the loss of migrant workers were killed, tortured, or imprisoned as if they did not get the government's attention and acute concern in power. Another study conducted by Utami in Amiruddin (2004), gender discrimination in Indonesian is related to the community's mindset, especially in families thinking that education is more important for boys than girls. It shows the inequality of treatment, which causes the girls' educations are lower than boys'. The text articulates Indonesian migrant workers' problems that experience the structural suppression dominance of agents of the Indonesian Manpower Services Company (PJTKI). The unclear mechanisms to corrupt practices in changing the age limit as a departure requirement to Indonesian Overseas Workers expect to be sources for policymakers to take firm action against any agency that has deceived and exploited Indonesian migrant workers. Agents, corrupt local officials who often took bribes to make false documents or passports are the ones who deserve the most imprisonment. The female migrant workers who dare to take a leap of faith and risk their lives should be defended, fought for, and protected for their rights.

This research is conducted to see from the approach of literary works that became the main discussion subject. A literary work can be a true story based on a personal interview, a diary, or someone's note. From the main character, the reader can know about their identities, thoughts, and ideas that sometimes point out the dark side of their past lives, which reveal to the public. The problems are procedures and mechanisms related to departure, waiting period until their controversial return - this research conduct to knock the door of government consciousness and Indonesian about migrant labor. The research's objective is to strengthen previous research, mainly to show the imbalance of gender relations, the dominance of the structural suppression system, and stereotypes on Indonesian women migrant workers, especially those with illegal status. The various expositions that become the biggest problem for women illegal Indonesian workers experienced it by the main character and the narrator in Burung-Burung Migran. This novel is fascinating to be studied and become the main corpus of the research.

The important point from this research is offering a discussion with narratology, and they are rarely analyzing the character in the migrant novel. Moreover, the concept is fit to see the discrimination, stereotype, and gender relation experienced by the novel's woman characters. This concept becomes the novelty in analyzing the woman's character in migrant novels.

\section{Methodology}

As a form of literary work with a fictional genre of biography novel, this has specificity because it tells the true story of the main character in the text. The qualitative narrative research method uses in this research. Furthermore, the text examines the concept of narrative strategies about characters and focalizations, gender and stereotypes to produce a complete discussion of discrimination, gender inequality, and power relationships that often encounter the story of their journey as migrant workers.

The novel of Burung-Burung Migran becomes the primary data of the research. Meanwhile, various sources in books, articles, journals, magazines, news articles, and websites related to the discussed topic as secondary data are also useful to complete the discussion. Characters and focalizations studied explicitly in the careful reading of this study. The writer will observe the usage of words, phrases, and sentences since the discussion closely relates to the focalization and the narrator's position in the novel.

According to Polkinghorne in Creswell (2010), narrative analysis is a paradigm that collects descriptions of events or incidents and then compiles them into stories using storylines. 
With a research corpus in a journal or diary, narrative analysis deems appropriate to reveal the writer's strategies. Narratology is the knowledge of storytelling as well as the structural analysis method of telling literary texts. Narratology is concerned with the technique of describing a novel and arranging it in a systematic way (Genette, 1980). In Narrative Discourse: An Essay in Method, Genette uses the terms narration or storytelling. Focalization, focalisator, and narrator from Genette used as analysis tools to study this research.

Genette's narratology categorization divides into three, namely tense, mood, and voice. Tense includes studying the temporal relationship between storytelling and storytelling; mood includes studying the narrative "representation modalities". In contrast, voice includes the study of storytelling's effect on storytelling, including the storyteller and the audience (audience), expressed or implied (Genette, 1980). In tense, Genette breaks the discussion into three subcategories, namely order, duration, and frequency. So, overall, Genette's narratology principal is divided into five things, namely (1) order, (2) duration, (3) frequency, (4) mood, and (5) voice (Genette, 1980).

Not all of these points use in this study. Two aspects in mood or mode, namely focalization and voice or speech, will be used. The focus of the discussion in this study is to look at the focalization and speech or narrator in both texts so that other discussions in Genette's narrative strategy will not carry out. According to Genette (1980), a story is a series of events that move chronologically from beginning to end, including characters, events, space, and time; whereas storytelling is the way a story tells. The narrator is a speaker or someone who becomes a voice in narrative discourse. The narrator is an agent who communicates with the recipient (reader), arranges the plan, and determines what to say or how to convey it. If necessary, the narrator will "fight" the comments and opinions with a purpose or message.
Genette (1980) distinguishes focalization into three types: storytelling is not localized or zero focalized, the storytelling is internally localized-that is the focalization with the focalisator is in the story or is one of the characters in the story-and the focalization is outside the characters in the story, external focalisator. This focalization with the viewer's location is the same as the viewer's location in the internal focalisator, namely focalization with the focalisator is in the story or is one of the characters in the narration. With differences in external focalisator narratives, the reader does not know what the focalisator thinks or feels. So, focalization is related to the position of the narrator in a story. A focalisator is someone who directs the orientation of the point of view in the narrative text or, in other words, acts as the subject of focalization, namely as a person who sees events or characters in the story (Luxemburg, 1991, p. 125).

There are two categories made by Genette (1980) based on the narrator's relationship with the story, namely, homodiegetic narrative and heterodiegetic narrative. The homodiegetic narrative is a story told by a present narrator in the form of a character in the text. The prefix "homo" refers to individuals who act as narrators who also act as figures in events. A text is homodiegetic when using first-person pronouns (I), while the heterodiegetic narrative is a story told by a narrator who is not present as a character in the text. The prefix "hetero" shows the "different world" between the narrator and the narrated event. Text with heterodiegetic type uses third-person pronouns. The narrator's absence is absolute. In homodiegetic, the narrator has a degree of presence, divided into two types, namely the narrator as the central figure in the story and the narrator as a secondary character who only functions as an observer or witness.

\section{Results and Discussion}

This study's results indicate that the theory of narrative (Genette, 1984) can reveal the object of focalization, namely the poor treatment of Indonesian woman migrant workers. The 
woman main character's position as a narrator and focalisator in this diary is getting more vital in presenting various forms of gender injustice, discrimination, and accepted stereotypes.

In this section, the discussion divides into three women as sexual objects, illegal migrant workers: vulnerable to deception, violence against women, and gender inequality. The three sub-discussions will reveal violent practices, discrimination, and stereotype that are often received by women migrant workers from the forms of words, phrases, and sentences used in the text.

\section{Women as Sexual Objects}

Burung-Burung Migran is a biographical novel based on the experience of a woman migrant worker named Sutik A. S. This text also has a specific theme to show gender injustice, violent practices, and discriminations. Moreover, she played an active role in women's empowerment movement with a Social Institution (LSM) in East Java. She regretted most, but still did not dispense her enthusiasm for helping the women in her village when she decided to return to Indonesia. At the same time, her husband, who was the main reason she went to Malaysia, chose to stay and work in Malaysia. According to Clara Reeve, the novel is a picture of the real-life and behavior. Novels are realistic. They develop from nonfictional narrative forms like letters, journals, memoirs or biographies, chronicles, or history (Wellek \& Warren, 2014). In addition, this novel is unique in the real experience of the woman character.

The type of focalization in the text is internal focalization, with the viewer being in the narrative and is one of the characters in the story. The narration in the form of a fixed internal focalisator, that is, the whole storytelling sees from just one character, Sutik. In the text, the narration spoke by an internal focalisator who also acts as the narrator. Another specialty is the internal focalisator, and the narrator is done by the main character so that everything in the text is conveyed directly to the main character. As a central woman character, Sutik focalizes violence and her struggle as an illegal migrant worker and a wife to the reader by demonstrating her sacrifice to survive in Malaysia by selling herself to be a prostitute woman.

Semalam itu, telah kutiduri dua puluh lakilaki. Dua puluh laki-laki, di tengah mimpiku akan kamu, akan tanah yang kamu pijak, dan anak-anakku yang merindukan bapaknya.

Last night, I slept with twenty men. Twenty men, in the midst of my dreams of you, of the land you stand on, and of my children who miss their fathers (Harlan, 2011, p. 14).

The object of focalization in the text is Sutik's sacrifice to become a prostitute woman to survive in Malaysia. Sutik's first step to come to Malaysia illegally is to find her husband, who works in Malaysia and has not given any news for a long time. The choices of words used in the text clearly show the woman characters being sexual objects, as in the phrase, I slept with the twenty men in the quote above. The averment of Sutik's character, who becomes a sexual object, uses the internal focalisator. The observation emphasized Sutik's helpless condition and volunteered for the sake of his search for her husband, who went to Malaysia. The focalization of women as objects is also revealed by the internal focalisator when her husband, who is supposed to be responsible, goes away and misses somewhere.

Tetapi, kamu telah benar-benar pergi, Yamin. Entah untuk apa. Tak ada yang kau tinggalkan sebagai jejak, juga tidak dari tempat yang jauh itu. Tak sepucuk kabar pun kamu layarkan dari sana. Bermalam-malam aku merenungi kepergianmu, kadangkadang sambil menangisi ketidak beradaanmu di dekatku.

But you have really left, Yamin. I don't know what for. There is nothing you leave as a trail, nor from that faraway place. You have not spread a word from there. Overnight I contemplate your departure, sometimes 
while weeping over your absence near me (Harlan, 2011, p. 23).

The narrative strategy's specificity in the text is writing using a journal or diary aimed at the figure of Sutik's husband named Yamin. The focalisator looked closely at Sutik's character complaining to the husband. Still about the focalization of women as objects, the internal focalisator also presented the life of a Sutik who force to get married at a very young age, 12 years. As a village woman, she could not resist coercion from her parents. The narrator voiced the stereotype that unmarried adolescent girls often accepted thirteen being called a spinster.

Menikah muda di kampung kami adalah sebuah kelaziman. Bahkan, keniscayaan. Bapak ibuku mempercayai itu, barangkali sebesar mereka memercayai keniscayaan Tuhan. Di tempat ini, Ketika seorang gadis sudah berumur 12 tahun, para orangtua akan bersicepat memasang sayap di punggungnya dan menepuk pantatnya supaya dia terbang cepat-cepat. Kalau pun ia belum ternoda oleh darah menstruasi, biarkan waktu memacunya. Sebab, jika 13 tahun sudah dia hidup sendiri, orang akan memanggilnya perawan tua. Orangtuaku, sebagaimana yang lain, tentu tak mau anak gadisnya yang cantik digunjingkan seperti itu.

Getting married in young age in our village is a norm, in fact, inevitability. My mother and father believed that, perhaps as much as they believed in the inevitability of God. In this place, when a girl is 12 years old, parents will quickly put wings on her back and pat her ass so she can fly quickly. Even if she has not been stained by menstrual blood, let time spur her. Because, if she has lived alone in her 13 years old, people will call her spinster. My parents, like the others, certainly don't want their beautiful daughters to be gossiped like that (Harlan, 2011, p. 29).

Focalization toward violence practices experienced by Sutik when she was a child showed how her life has been filled with violence since she was young, and at the same time suffering because women are very close to various stereotypes attached. Women become victims in the village where they live. The internal focalisator has also observed the tradition of getting married at a very young age following the quote.

Belenggu itu bernama perjodohan. Ketika aku berumur tiga belas tahun, belum lama setelah keluar dari Sekolah Rakyat, mereka mempertemukan aku dengan seorang lakilaki berumur lima tahun lebih tua dariku. Laki-laki yang keluarganya akan segera datang untuk meminangku. ...Saat aku begitu ingin mengenyam bangku SMP, mereka telah memenjaraku dalam perkawinan. Dengan dia yang tak pernah kucintai.

Shackles are called matchmaking. When I was thirteen, not long after leaving Sekolah Rakyat, they met me with a man five years older than me. A man whose family will come soon to ask for my hand....When I wanted to go to junior high school so badly. With him whom I have never loved (Harlan, 2011, p. 29).

The right diction selection shows Sutik's character as a woman who suffered since a teenager, described by the focalisator and narrator clearly in the text from the sentence Shackles is called matchmaking. Through the sentence Shackles are called matchmaking, the internal focalisator described that Sutik got suffering from an arranged marriage at her young age, so she could not continue her education in junior high school. Moreover, the focalisator also shows Tutik is suffering from the other sentences; when I wanted to go to junior high school so badly; they had imprisoned me in marriage.

Complementing women's stories as objects also presented by the homodiegetic narrator happened to several other women illegal migrant worker characters. The women become the victims of poverty, do not have the expertise, and can only surrender to fate when becoming a 
sexual object of the men on the way to the shelter.

Berkali-kali aku dijamah, mulai oleh bapakbapak berjaket kulit yang bau keringat sampai pemuda ganteng yang matanya liar seperti orang gila. Aku menolak dan menutupi tubuhku dengan lengan, tapi mereka tidak menyerah.

I was touched many times, starting from the old man in leather jacket that smelled of sweat to handsome young man whose eyes were wild like a crazy man. I refused and covered my body with my arms, but they did not give up (Harlan, 2011, p. 60).

The internal focalisator also focalized another woman migrant worker, Sulis, who also became the victim of an agent's brutality in the shelter. The focalization of sadness and resignation mixed with the flat tone depicted in the voice gave rise to her bitterness.

Aku sudah nggak gadis lagi sekarang, Mbak, dia tersenyum tipis. Senyum yang pahit. Tetapi, suaranya tak sedikit pun bergetar. Datar. Seolah-olah tak ada yang mengejutkan dari kalimatnya. Kapan? Tadi malam. Tadi malam kami baru saja sampai di tempat ini. Aku diajak keluar sama Bang Rais. Rais adalah petugas PJTKI yang menampung kami di rumah ini. Mau jalanjalan ke took baju, katanya. Tapi, tahu-tahu aku diajak mampir ke rumah di sono, dagunya terangkat sedikit, menunjuk ke utara. Kos-kosan anak laki. Sudah deh. Suaranya terdengar kering dan getir. Barangkali tak ada lagi rasa sakit. Tetapi, tidak sakit bukan berarti tak terluka.

I'm not a virgin anymore, she smiled thinly. Bitter smile. However, her voice did not vibrate at all. Flat. As if nothing surprising from the sentence. When? Last night. Last night we just arrived at this place. I was invited out with Bang Rais. Rais is a PJTKI officer who accommodates us in this house. Asking me to go to the clothes shop, he said.
But suddenly I was invited to stop by that house, her chin lifted slightly, and pointing north. Boarding boys. I have done it. Her voice sounded dry and bitter. Perhaps there is no more pain. But painless does not mean not feeling the pain (Harlan, 2011, p. 8586).

The homodiegetic narrator focalized Indonesian woman migrant workers who uneducated, illegal, and did not have the skills that led them to their poor treatment. This localization reinforces the stereotype that women are not smart, uneducated so that their work is as a laborer.

Amiruddin (2004) stated that the recognition of some woman migrant workers who lost their virginity on their way to the last stop seemed to perpetuate a genuine effort and determination not accompanied by a skillful provision that would leave only and sadness. The inner wound leaves a black dot that can never erase in the emotional memory. Gender injustice and discrimination are focalizations that the narrator observes, showing that many women migrant workers are often victims. Ironically, they could not fight back. This novel complements some of the writer's works that portray the lives of female migrant workers who often experience violence, gender injustice, and stereotypes. The long journey filled with human tragedy makes this novel interesting to observe.

The long route from Surabaya-JakartaLampung-Padang-Riau-Batam-Tanjung Pinang by buses inevitably raises an opportunity for the masseuse's men to benefit over the suffering of these illegal woman migrant workers. The money supply depleted, the immediate need to eat and drink that must always fulfill, and the absence of a straightforward procedure from the recruitment agencies that dispatch them to make the path they take that seems to leave no choice. They seem destined to surrender and accept fate, whatever it is. It is tragic to see the portraits of the journey and life presented in this biographical text to show our empathy and concern. 
The Indonesian woman migrant workers who do not have the skills and capabilities that support to obtain jobs that rely on their expertise are often an easy target for employment agencies in both Indonesia and Malaysia. They practice illegal human trafficking or illicit shipments. As a result, they later fell into the practice of prostitution. Even unlawful migrant workers expelled to the border neglected and forced to prostitute in Entikong (Hairiah, 2004). Many children are born without knowing their fathers, do not have the opportunity to go to school, and less of having sufficient medical treatment. These are just a few of the problems that arise due to illegal labor shipments that negatively impact the perpetrators of unlawful labor-sending practices.

One of the places known for human trafficking in Indonesia is Batam, one of the destination areas of trafficking victims from Java, Sumatra, Kalimantan, and Sulawesi (Manado). Batam is also known as the shipping area and transit area for trafficking victims to Malaysia (Kuala Lumpur, Sarawak), Singapore, Brunei Darussalam Border, Japan, Hongkong, Taiwan, and Australia (Wagner, 2004).

Furthermore, the homodiegetic narrator also told another woman character in the text, Mus, who chose to survive and earn a living by selling herself to construction workers. Women as sex objects are not the best choice, but sadly, they do their best to earn extra money. They, migrant workers, undergo a dual profession as workers and prostitutes.

Tiap Sabtu pagi, kami diajak jalan-jalan sama Syamsudin, orang ejen. Dimulainya kisahnya dengan lambat-lambat. Jam lima pagi, sudah dibangunkan. Disuruh mandi. Habis itu, kami disuruhnya masuk ke dalam mobil boks. Dibawa ke mana, Mus? Ke blokblok bangunan. Sekitar jam tujuh pagi, pintu mobil boks dibuka. Mobil parkir di depan kongsi. Lalu, habis pintu dibuka, Din turun dari tempat sopir. Jalan dia ke arah container. Teriak-teriak kayak tukang sayur. 'Ayam, ayam, ayam! Ayo, segar, ayam, ayam!
Mus berhenti bercerita. Ayam? Lantas, tak digubrisnya komentarku, keluar orangorang dari container, Mbak. Laki-laki semua. Lha, iya. Wong itu proyek bangunan, kok. ... Menengok kami-kami, yang mendekam di dalam boks belakang. Pilih-pilih. Aku tahu apa yang dirasakannya. Tapi lumayan. Sekali diajak ke dalam kontainer, kami dapat komisi tiga ringgit untuk tidur dengan seorang laki-laki. Setiap Sabtu, aku bisa kumpulkan dua sampai tiga puluh ringgit. Bisa buat jajan.

Every Saturday morning, we are invited to go out with Syamsudin, an agent. The story begins slowly. At five in the morning, we have been woken up. Was told to take a shower. After that, we were told to get into the boxcar. Where were you taken, Mus? To the building blocks. Around seven in the morning, the door to the boxcar was opened. The car is parked in front of the company. Then, after the door opened, Din got down from the driver's place. Go to the container. Shouting like a vegetable handyman. 'Chicken, chicken, chicken! Come on, fresh, chicken, chicken! Mus stopped telling stories. Chicken? Then," she commented, people came out of the container. All men. Yes. That is a building project. ...Looked at us, who were languishing in the back box. Picky. I know how she feels. But not bad. Once invited to a container, we get a three-ringgit commission to sleep with a man. Every Saturday, I can collect two to thirty ringgits. Can buy snacks (Harlan, 2011, p. 152-153).

The use of the word "chicken" as a metaphor shows the focalization in the text is rich in diction, which reinforces the suffering of migrant workers voiced in the text. Chicken has a metaphor meaning a village woman who worked as a prostitute. The depiction of women as chickens is considered very degrading to women. The use of metaphoric language in describing women further strengthens the focalization of violence against woman migrant workers. 
Journal of Language and Literature

ISSN: 1410-5691 (print); 2580-5070 (online)

\section{Illegal migrant workers: vulnerable to deception}

Invoicing bad treatment and injustice, Harlan, as the writer, looks in-depth and specific in discussing the events those illegal women migrant workers experience so that the message to convey to readers becomes very real. The practice of deception is the next subject discussed by the narrator. The narrator and the internal focalisator told that she had been a victim of fraud from his employment agency in Singapore. Her salary for eight months working in Singapore did not pay as agreed in the beginning.

900 ringgit. Aku tercenung di meja administrasi ejen. Bukankah seharusnya jumlah RM 2.240? Kenapa hanya sekian, Cik? Tanyaku gagu. Aku gagal mengerti. Mustinya berapa kau sangkakan? Dua ribu dua ratus empat puluh ringgit, Cik. Saya kerja delapan bulan. Gaji saya tiap bulan RM180, seturut Cik Liao. Ya, benar. Gaji kau sebulan RM180. Tapi lima bulan pertama, kau musti bayar ongkos kirim kau kemari, jadi tadalah, gaji. Habis tu, ada potongan RM50 setiap bulan. Lalu, dikurangkan lagi dengan levi (life fee), RM200 untuk dua tahun. Ongkos administrasi untuk tamping kau 'kat ejen sini lagi RM500. Pajak dan potongan lain-lain RM290. Jadi berapa? Betul tak RM900, hai Indon? Aku merasa gagal memahami system pembayaran ini. Ongkos mengirimku kemari - bukankah aku sudah membayar 150 ribu rupiah Ketika berangkat dulu?

900 ringgits. I was stunned at the agent administration desk. Shouldn't I receive RM 2,240? Why only so, Cik? I asked hesitantly. I failed to understand. How much should you expect? Two thousand two hundred and forty ringgit, Cik. I worked eight months. My salary is RM180 per month, according to Cik Liao. Yes, you're right. Your salary is a month of RM180. But in the first five months, you have to pay your delivery fees to come here, so there isn't salary anymore. After that, there is a RM50 cut every month. Then, deducted
Hiqma Nur Agustina

again with a levi (life fee), RM200 for two years. The administrative costs for escorting you to agent here again are RM500. Taxes and miscellaneous deductions are RM290. So, how many? Isn't that right RM900, Oi Indon? I feel like I failed to understand this payment system. The cost of sending me here - didn't I pay 150 thousand rupiah when I departure (Harlan, 2011, p. 146-147).

The internal focalisator also voiced the deception experienced by another woman migrant worker character; Mus. Mus is an Indramayu woman. Indramayu is a place where many people work as migrant workers in Indonesia. Being a migrant worker in Singapore led her to receive various forms of abusive, fraudulent treatment, and the worst, she was also trapped as a prostitute.

Ya udah. Pulang aku ke ejen. Eeh, sampe sana sial lagi. Gajiku nggak dibayar. Katanya, habis buat potongan ini-itu. Malah masih utang. Kali ini dia tertawa. Utang? Kok Bisa? Aku teringat pengalamaku sendiri tadi siang. Naik darah aku dibuatnya. Iya. Aku kerja lima bulan ndak dibayar lho, Mbak. Mustinya kira-kira aku dapat uang 1.000-an ringgit. Eh, kok malah dibilang masih punya hutang. Ah. Benar-benar gila.

Alright. I went home to agent. When I was there again unlucky me. My salary isn't paid. She said that my salary was used for some matters. Even still I have debt. This time she laughed. Debt? How come? I remembered my own experience this afternoon. The agent made me angry. Yes. I haven't been paid for five months. I should have paid ringgit 1,000 in cash. How she said I still have debt. Ah. That's insane! (Harlan, 2011, p. 151).

Focalization, in the form of deception, is vulnerable to Indonesian woman migrant workers. They are often powerless to fight back and always become victims. The injustice they receive makes them always persecuted. In line with Harlan, Suryomenggolo (2012) states the literature on Third World women workers long ago moved beyond the stereotypes of docile, 
passive, and politically unconscious women or cases framed for global consumption in the name of "international solidarity". We cannot say that the experience of Sutik and some of the woman migrant workers is a minor case. In the form of a cut in salary, the inhuman treatment, which resulted in a loss of salary, made this woman worker experience violence. The author's effort in presenting the true story of the woman character Sutik and several other women should be appreciated.

\section{Violence against Women and Gender Inequality}

The internal focalisator also succeeded in voicing the violence often experienced by Indonesian women migrant workers. They described as not being able to fight, surrender, and only pray for God's help. In line with Utami in Amiruddin (2004), gender discrimination in Indonesian is related to the community's mindset. As a result, the girls did not have an equal opportunity to continue studies at school or in the workplace. It shows the inequality the narrator presents Mus' character, who experienced great suffering from his Singapore employer.

Aku dipukuli sama majikanku, Mbak, katanya getir. Setiap hari, selama dua minggu lebih, aku ditanyai. Dimana aku simpan gelang emas majikanku. Habis barang-barang dan lemariku mereka geledah. Ya ndak ada, wong aku memang ndak pernah mencuri kok.

I was beaten by my employer, she said bitterly. Every day, for more than two weeks, they ask me the same question. Where I keep my employer's gold bracelet. They ransacked my belongings and my cupboard. There isn't, because I really never steal (Harlan, 2011, p. 150).

The increasingly inhumane treatment voiced by the homodiegetic narrator presents factual information about the plight of suffering Indonesian woman migrant workers in the following quotes.
Tapi majikanku wadon-ku makin marah. Bukannya sadar. Aku diajar pake gagang sapu, di-slomot pake setrika, disiram air mendidih. Mus menggeleng-geleng kepala. Habis itu aku dikeluarin. Ah. Masih untung aku dikeluarin, Mbak. Coba kalau aku dibawa ke kantor polisi. Habislah aku.

But my lady employer is getting angrier. Not aware. I was taught to use a broom handle, slashed with an iron, and boiled with boiling water. Mus shook her head. After that I was released. Ah. Luckily, I'm out. If they send me to the police station. I'm over. (Harlan, 2011, p. 150).

The narrator presented some quotations to show the cruelty of the employer toward Indonesian woman migrant workers. The continuous focalization shows the violence and poor treatment experienced by migrant workers in the country where they work. This narrative strategy is continuously carried out by the narrator in the text and influences the reader to know and sympathy the violence and repression experienced by the women migrant workers.

All forms of injustice and conditions that repress woman migrant workers who are not sufficiently protected at that time present a space for the reader to be able to see honestly, empathically, and caring about the fate of others. Gender inequality and violence undeniably sheltered behind the patriarchal constructions used to control and subjugate women. The irony is that they are considered legitimate. Therefore, feminists believe that violence against women is patriarchal and systemic (Bhasin, 2002). It means that the existing system is predominantly dominated by men, while women only accommodated in various ways. For example, migrant workers can play a significant role because their existence is needed, but this does not mean they can exercise control. The contradictions that emerge even women sometimes also support and perpetuate patriarchy. Most of the women have internalized patriarchal values and are not always free from the ideology of patriarchy. 


\section{Conclusion}

Based on the results of the discussion, the conclusions of this study are. First, the type of focalization in the text is an internal focalisator and a homodiegetic narrator. Burung-Burung Migran tried to voice Indonesian woman migrant workers who try to get independence and their rights echoed by Sutik character through her observations as an internal focalisator and, at the same time, a narrator with homodiegetic type. The use of the homodiegetic narrator has a more personal and profound effect, especially the text's genre is a biography of the novel in a journal or diary.

The narrative text strategy of BurungBurung Migran in voicing inequality, discrimination, and various acts of violence can see in words, phrases, and sentences. That is very close to the issue of violence, both verbal and sexual harassment. The nickname as a hero of foreign exchange should be an essential thing that the government regards in formulating policies and providing real protection against all forms of ill-treatment and violence they receive, thus ceasing to cause further casualties. The clear and strict regulation and supervision in recruiting prospective Indonesian migrant workers and employment agencies may prevent them from structural oppression and treatment. That is so lowering their self-esteem as women so that there is not Sutik, Mus, Sulis, Rina, and other names known as victims of injustice, the violence of their status as Indonesian woman migrant workers.

\section{References}

Andriyeni, S. N \& Ambasari, R. D. (2017). Kaleidoskop Kekerasan dan Pelanggaran Hak Perempuan Buruh Migran 2016: Menagih Tanggung Jawab Negara untuk Melindungi Perempuan Buruh Migran. Jakarta: Solidaritas Perempuan.
Amiruddin, M. (2004). Eksploitasi Seksual dalam Perdagangan Anak, Korban Terbesar adalah Anak Perempuan. Jurnal Perempuan, 29, 127.

Balakrishnan, B. (2013). Circular Migration of Indonesian Low Skilled Labour Migrants to Peninsular Malaysia: Patterns, Causes, and Consequences. Ph.D. Dissertation. The University of Adelaide, Australia.

Bhasin, K. (2002). Memahami Gender. Jakarta: Teplok Press.

Constable, N. (2009). Migrant Workers and the Many States of Protest in Hong Kong. Critical Asian Studies, 41(1), 143-164.

Creswell, J. W. (2014). Research Design. Qualitative, Quantitative, and Mixed Methods Approaches. Fourth Edition. California: SAGE Publications, Inc.

Genette, G. (1980). Narrative Discourse: An Essay in Method. New York: Cornel University Press.

Hairiah. (2004). Sekilas Gambaran Perdagangan Perempuan dan Anak-anak di Kalimantan Barat. Jurnal Perempuan, 29, 8-9.

Harlan, M. \& Sutik A. S. (2011). Burung-Burung Migran. Bandung: Mizan Media Utama.

Hasan, R. A. (2017). Kemlu Jelaskan Polemik TKI di Malaysia. Liputan 6. 7 Juli. Retrieved from: http://global.liputan6.com/read/3015116/ kemlu-jelaskan-polemik-tki-di-malaysia. (Accessed 10 March 2020)

Luxemburg, et.al. (1991). Pengantar Ilmu Sastra. Jakarta: Pustaka Pembangunan Swadaya Nusantara.

Martyn, H. L. (2019). Toward a Cross-Cultural Training Model for Migrants Entering Oppressive Work Environments. International Education Studies, 12, 2. 
Munti, R. B. (2006). Sejauh Mana Negara Memperhatikan Masalah Perempuan? (CEDAW dan Pertanyaan-pertanyaan tentang Kebijakan-kebijakan Negara). Jurnal Perempuan, 45, 7-8.

Pusat Data dan Informasi, BP2MI. (2020). Data Penempatan dan Perlindungan PMI. Periode September 2020. https://www.bnp2tki.go.id/uploads/statist ik/images/data_21-102020_Laporan_Pengolahan_Data_BP2MI_Se ptember_.pdf

Pusparani, S. P. \& Ani W. S. (2017). Perempuan dan Upaya Pemberdayaan Diri: Studi Kasus terhadap Enam Perempuan Pekerja Rumah Tangga Migran Indonesia. Jurnal Perempuan, 22(3), 7-8.

Sholihah, H. (2004). Bayi pun Dijual. Jurnal Perempuan, 29, 91-94.

Sitorus, M. (2006). Menjamin Hak Perempuan dan Anak Melalui Konvensi. Jurnal Perempuan, 45, 118.

Stasiulis, D. K \& Bakan, A. B. (1997). Regulation and Resistance: Strategies of Migrant Domestic Workers in Canada and Internationally. Asian and Pacific Migration Journal, 6(1):31-57 DOI: $10.1177 / 011719689700600103$

Suryomenggolo, J. (2012). Factory Employment, Female Workers' Activism, and Authoritarianism in Indonesia. Reading Ida Irianti's Pembelaan. Critical Asian Studies, 44(4), 597-626.

Wagner, L. (2004). Trafficking Perempuan dan Remaja untuk Tujuan Eksploitasi Seksual Komersial di Batam. Jurnal Perempuan, 29, 24-25.

Wellek, R. dan Austin, W. (2014). Teori Kesusastraan. Jakarta: Gramedia. 